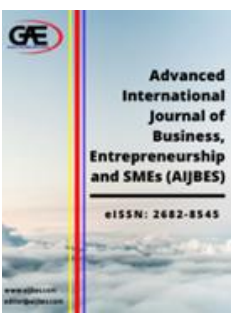

\author{
ADVANCED INTERNATIONAL JOURNAL OF \\ BUSINESS, ENTREPRENEURSHIP, AND SMES \\ (AIJBES) \\ www.aijbes.com
}

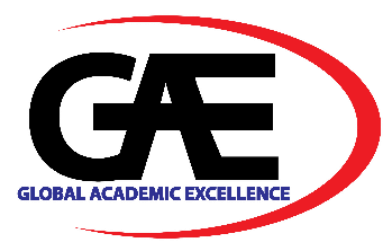

\title{
EFFECT OF COVID-19 PANDEMIC ON SME PERFORMANCE IN NIGERIA
}

\author{
Bukar Ali Bularafa $^{1 *}$, Umar Garba Adamu ${ }^{2}$
}

1 Department of Business Administration and Management, College of Administration, Management and Technology (CAMTECH), Potiskum, Yobe State, Nigeria

Email: abbularafa@gmail.com

2 Department of Marketing, Mai Idriss Alooma, Polytechnic, Geidam, Yobe State, Nigeria

Email: garbaumar2005@gmail.com

* Corresponding Author

\section{Article Info:}

\section{Article history:}

Received date: 10.02 .2021

Revised date: 18.02 .2021

Accepted date: 21.02 .2021

Published date: 01.03.2021

\section{To cite this document:}

Bularafa, B. A., \& Adamu, U. G. (2021). Effect of COVID-19 Pandemic on SME Performance in Nigeria. Advanced International Journal of Business, Entrepreneurship and SMEs, 3 (7), 75-92.

DOI: $10.35631 /$ AIJBES.37007.

This work is licensed under $\underline{\text { C B BY } 4.0}$

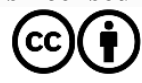

\begin{abstract}
:
Small and Medium Scale Enterprises (SMEs) are undeniably playing a significant role in the economic development of many countries globally. This role performed by the SMEs has been distracted by the global pandemic COVID-19 (Coronavirus). The pandemic brought about lockdown, movement restrictions, market closure, social distancing, etc. Thus, these restrictions and controls of the movement have particularly affected small and medium enterprises (SMEs) in Nigeria. This study aims to examine the effect of the coronavirus pandemic on the small and medium scale business in Yobe State, Nigeria. The study adopted a survey research design. Data were obtained through a questionnaire administered to 278 SMEs in Yobe State. The data were analyzed using descriptive and regression analysis using SPSS. The findings of the study indicate owners/managers of SMEs that participated in the study rated the variables of COVID-19 (lockdown, movement restriction, market closure, and social distancing) on a high level. The result further revealed that all the variables in the study correlate with SME's performance. Interestingly, the findings indicate three variables have a significant positive effect on SME's performance, the highest among is the market closure, followed by movement restriction and lockdown accordingly. While social distancing shows no significant effect on SME's performance. Therefore, it is recommended that proactive plans should be put in place for SMEs in anticipation of events such as COVID-19 that can hurt businesses. Finally, future research should consider other related variables that have not been considered in this study.
\end{abstract}

Keywords:

Coronavirus, COVID-19, Pandemic, SMEs, Nigeria 


\section{Introduction}

\section{Background of the Study}

Small and medium scale enterprises undeniably critical to the growth and development of the global economy. The SMEs subsector becomes a good source of job creation, aid in the development of local technology and source of development to indigenous entrepreneurs (Alaye-Ogan, 2012; Erdem, 2011), and enormously contributed to nation-building (Aderemi, Olu-Young, Taiwo, \& Adejumo, 2019; Tehseen \& Ramayah, 2015). The SMEs sector contributed more than $90 \%$ of all economic activities and more than $50 \%$ of all employment opportunities globally and also, accounted for more than $40 \%$ of GDP in developing nations (Garba, 2020). SMEs sub-sector in Nigeria, as obtains in other parts of the globe, performs a key role in the economic development of the country. They accounted for $90 \%$ of all businesses in Nigeria (Gbandi \& Amissah, 2014).

Although, according to World Bank SMEs are businesses with a maximum of 300 employees. In Nigeria, SMEs are regarded as businesses with less than 50 employees and capital which includes; the cost of machinery and equipment less or equal to $\$ 600,000(\$ 1,600)$ which is owned independently with the hope of generating profit and meeting sales standard (CBN, 2018). Statistics from the National Bureau of Statistics indicated that the number of SMEs in Nigeria was estimated to be 41.1 million (ILO, 2017). The distinctive nature of SMEs was a result of the use of local raw-materials, employment generation, promotion of rural development, nurture entrepreneurial activities, mobilization of savings locally, and opportunity for self-employment (Aderemi, Ojo, Ifeanyi, \& Efunbajo, 2020).

However, Covid-19 Pandemic has a devastating effect on human and material resources and it is one of the greatest events that history will continue to remember. The pandemic spread across the globe without obstacles and the worst that affected the global economy since the great depression (Erdem, 2011; IMF, 2020; WHO, 2020). The case first emerged in Wuhan, China, in 2019 which result in a toll of death that extends to almost all countries of the world (Akanni $\&$ Gabriel, 2020). The total number of confirmed cases across the globe was 16, 301,736 as of $28^{\text {th }}$ July 2020, whereas casualties stood at 650,069 . In trying to control the spread of the pandemic factories, markets, places of worship were closed, as well as restrictions of movement of people, goods, and service. This always echoed its effect on the activities of SMEs globally.

Business organizations were not prepared for the pandemic, despite the call by the Public Health Research Institute to adopt precautionary measures on the emergency of such type of events, except big firms were able to take a bold step plan against the pandemic (Rebmann, Wang, Swick, Reddick, \& del Rosario, 2013). It is anticipated that the US GDP will likely decrease to 3.8 percent for 2020 due to the pandemic (Hatzius, Philips, Mericle, \& Struyven, 2020). Furthermore, Igwe (2020), stressed that the global economy will witness the worst economic recession as a result of the pandemic. The global economy is predicted to record economic losses through three outlets: supply chain, demand, and the financial market. These outlets hurt businesses, household consumption, and international trade.

In Nigeria, the case of the pandemic was first discovered on $27^{\text {th }}$ February 2020. The Nigerian Centre for Disease Control (NCDC) recorded 41,804 cases as of $28^{\text {th }}$ July 2020, out of this number 18,704 were discharged and 868 deaths. The SMEs sector in Nigeria has been seen as a tool that propelled the economy because of its ability to promote productivity, generate 
Volume 3 Issue 7 (March 2021) PP. 75-92 DOI 10.35631/AIJBES.37007

employment as well as improving the welfare of the people (Abosede \& Onakoya, 2013). In an attempt to halt the spread of the pandemic, the government take various measures ranging from the closure of borders, restrict the movement of people, goods, and services, as well as the closure of markets and worship places. Therefore, on $29^{\text {th }}$ March 2020, the government declared a total lockdown in three states, thus; Lagos, Ogun, and the Federal Capital Territory, Abuja, preventing all activities that are not essential in all those states. Afterward, the remaining states were also lockdown as well as banned on interstate movement except for essential services. This is one of the major reasons why many studies on the effect of COVID19 on SMEs in Nigeria cannot be overlooked in the time of this global pandemic.

However, many analysts have predicted a decrease in aggregate demand and supply, declining in exports, and an increase in government expenditure due to the negative effects of lockdown among various sectors of the Nigerian economy. Furthermore, this lockdown will probably make the situation terrible for SMEs in the country. As rightly indicated SMEs form the larger businesses in Nigeria with 141.1 million SMEs spread across the country, which employed more than $70 \%$ of the working population in the country (ILO, 2017). This indicates that large proportions of people in Nigeria are involved either directly or indirectly in SMEs. Then, any adverse economic tremors echoed by the COVID-19 pandemic on these sub-sectors put more than $70 \%$ of the working populace exposed to the unique virus.

\section{Problem Statement}

The global pandemic referred to as COVID-19 (Coronavirus) has caused a lot of damages to the world economy. To curtail the spread of the virus has brought about lockdown, a social distancing that results in the closure of markets, public offices, business organizations, places of worship, and events, the extent to which the virus spread and uncertainty about the situation have let consumers and investors run away for safer consumption and investment (Ozili \& Arun, 2020). Also, the restriction on the movement of people, goods, and services in many countries causes great losses for businesses and industries which include; aviation, entertainment, hospitality, and sports. The aggregate loss globally was projected to be more than $\$ 4$ trillion (Ozili, 2020).

The lockdown measure imposed has affected the purchasing rate of consumers, the percentage change fell from 59.2\% to $41.1 \%$ from January 2020 to June 2020 which affects the productivity of the manufacturing sector of SMEs (Central Bank of Nigeria, 2020). Statistics also indicate there is an upward trend in unemployment in Nigeria from $23.1 \%$ to $33.5 \%$ in 2019 and 2020 respectively due to COVID-19 which put the population of unemployment around 39.5 million people (National Bureau of Statistics, 2020). Also, the poverty rate has increased during the lockdown period by $8.7 \%$ i.e. from $43.5 \%$ to $52.2 \%$ which indicates 17 million more people falling below the poverty line (Andam, Edeh, Oboh, Pauw, \& Thurlow, 2020).

Therefore, as a result of this, some SMEs cannot withstand the situation for more than one month due to cash flow problems (Farrell \& Wheat, 2016). Furthermore, SMEs face the risk of total closure aftermath of the pandemic, partially due to the inability to settle their accruals during the closure (Schrank, Marshall, Hall-Phillips, Wiatt, \& Jones, 2013). Many businesses were forced to lay off some of their staff, whereas others had to reduce their number of working hours (Edgecliffe, 2020). The global pandemic has caused serious socioeconomic damages, the ban on sporting, religious, political, and cultural events, brought about widespread shortages of supplies (Turner \& Akinremi, 2020). In China, the decrease in consumption coupled with 
Volume 3 Issue 7 (March 2021) PP. 75-92

DOI 10.35631/AIJBES.37007

an interruption in production distorted the global supply chains which affect many firms in many countries of the world (Fernandes, 2020), particularly, Nigeria which depends mostly on China.

Environmental shock exposes an SME to a greater extent of strategic uncertainty, which has effects on the routine activities of SMEs and may, in some cases threaten its survival (SullivanTaylor \& Branicki, 2011). Many countries around the world are facing unprecedented challenges due to COVID-19 Pandemic (UNDP, 2020). Nigeria is not an exception. There is still a paucity of research on the effect of the COVID-19 pandemic on SME performance in developing countries, especially concerning business continuity (Fabeil, Pazim, \& Langgat, 2020). Since the SMEs contribute to the job creation and economic growth of the country and the unavoidable threats and tremors of COVID-19 to all the segments of the economy, particularly SMEs. Therefore, the study of this nature is necessary considering the contributions of this sector and the paucity of research in this area.

\section{The Objective Of The Study}

The main objective of the study is to examine the effect of the COVID-19 pandemic on SME's performance in Yobe State Nigeria. While the specific objectives were to:

1. Determine the level of the effect of COVID-19 pandemic on SMEs performance in Yobe State Nigeria

2. Examine the effect of lockdown, movement restriction, market closure, and social distancing due to COVID-19 pandemic on SMEs performance in Yobe State Nigeria.

3. Determine among the variables of COVID-19 most impacted on SMEs performance in Yobe State Nigeria.

\section{Research Questions}

1. What is the level of the effect of the COVID-19 pandemic on SME's performance in Yobe State Nigeria?

2. Does the variables; lockdown, movement restriction, market closure, and social distancing affects SME's performance in Yobe State, Nigeria?

3. Which of the variables of COVID-19 most impacted on SMEs performance in Yobe State Nigeria?

\section{Literature Review}

\section{Definition of Coronavirus (COVID-19)}

The concept 'Coronavirus' is an infectious disease that is popularly referred to as COVID-19 (Moore, 2020; Ohia, Bakarey, \& Ahmad, 2020). The virus was first discovered in Wuhan, China which was spread globally. The virus can infect human beings and animals which causes different types of respiratory sickness. The sign of the infection are running nose, sneezing, cough, fever, sore throat, breathing disorder, etc (Harapan et al., 2020; Ohia et al., 2020; Unhale et al., 2020). The disease is highly infectious (Shereen, Khan, Kazmi, Bashir, \& Siddique, 2020). Many people that were infected with the virus experience respiratory disorder and do not require any treatment to recover. Mostly, the elderly and those with medical problems such as cardiovascular disease, diabetes, chronic respiratory disease, and cancer are developing 
Volume 3 Issue 7 (March 2021) PP. 75-92

DOI 10.35631/AIJBES.37007

severe sickness. Therefore, the only way to prevent and reduce the spread of the virus is to be well enlightened about the deadly virus, its sources, and how it spreads (WHO, 2020).

The major avenues through which individuals are contacted with the virus are from the droplets of saliva/discharge from the nose when an infected person coughs or sneezes (Harapan et al., 2020). Therefore, it becomes necessary for people to adopt measures such as lockdown, social distancing, quarantine, and also, observation of simple hygiene which include; washing hands regularly, wearing facemasks, coughing into the flexed elbow, etc (Ohia et al., 2020). Although there are still ongoing medical tests assessing possible treatment by many countries and international organizations like WHO. Until now there are no specific vaccines or treatments for the virus called COVID-19 (Shereen et al., 2020).

\section{Theoretical Underpinning}

The study used two underpinning theories which include the System Theory and the SocialEcological Theory. The System Theory by (Boulding, 1956; Bertalanffy, 1951) was made on the assumption that "the whole is more than the sum of its parts". Meaning that individuals perform different types of roles that result in specialization and segmentation, which eventually result in a common interdependence between units. A unit cannot stand and function without depending on others (Durkheim, 1984). Generally, there are three most known boundaries of social systems are Micro System, Mezzo System, and Macro System. Micro System refers to the small size social system example individuals and couples. The Mezzo System refers to intermediate size system example groups and extended families. Macro System refers to large systems example communities and organizations. However, each level stands as a unit of a whole with a different property that differentiates it from other systems (Friedman \& Allen, 2011), which Bertalanffy referred to as the system's boundary. Thus, COVID - 19 is interpreted as an element that breaks the boundaries of well-being, and social systems, which are normatively defined.

Furthermore, many communities or societies give value to shared culture and interaction within families, communities, groups, and organizations, therefore, these societies commonly suffering major weak health structures and low health consequences. Hence, the spread of COVID-19 is inclined. The relevancy of this theory to this study is that organizations can use many plans (i.e. loosen or tighten) in responding to a challenging situation. Therefore, SMEs need to take appropriate safeguarding measures on huge tremors that may shake the society in the occurrence of tragedies such as COVID-19.

The Social-Ecological Theory (Bookchin, 1960) offers an understanding of behavioral reactions from a person, interpersonal, organizational, community, and public policy concerning the formation of behavior within the nearby social environment. The theory assists in the recognition of issues affecting behavior and also offers direction for developing successful programs through social environments. The social-ecological theory emphasizes the numerous levels of influence (such as individual, interpersonal, organizational, community, and public policy) and the idea that behavior is shaped and shaped by the social environment. The philosophies of Social-ecological Theory are connected with Social Cognitive Theory perceptions which propose that providing an enabling environment that results to change is significant in making it easier to implement healthy behavior.

With the emergence of COVID-19 which separates Nigeria from other countries of the world, serious attention should be given to shaping and adopting healthy behavior such as sanitization, 
Volume 3 Issue 7 (March 2021) PP. 75-92

DOI 10.35631/AIJBES.37007

social distancing, movement restriction, ban on worship, testing suspects, isolation, quarantining, and business closures. The relationship between the theory and this study is a detailed understanding of the reasons why people behave the way they behave. Therefore, SMEs that can alter the way they do things during and after COVID -19 will survive and prosper.

\section{The Linkage between COVID-19 Pandemic and SMEs Performance}

The deadly disease (COVID-19) has spread to almost everywhere in the world at an incomparable level. Governments are uncertain when the virus will vanish and the infection decline. In trying to tackle the spread of the virus, many countries have lockdown all or part of their country in an attempt to prevent the spread of the virus. Therefore, because of the lockdown business and economic activities have been affected and have weakened the available human and economic resources such as workmen, materials, transport, etc (Craven, Liu, Mysore, \& Wilson, 2020). This has caused the closure of many businesses and equally affected their performance. The lockdown, movement restriction, market closure, and social distancing as announced by the government has also truncated the movement of goods and services which stand as the backbone and which the SMEs depend on for their smooth routine activities.

SMEs together with their employees are an integral part of social and economic systems of day-to-day life globally. This important role played by SMEs now is facing threats from unmatched effects of coronavirus. The customers, as well as facilitators of SMEs, are under the threat of business bankruptcy as a result of the recession experienced globally (Wuen and $\mathrm{Wu}, 2020$ ). However, in such conditions controlling the virus, maintaining employee pay, reduction in long-term costs, and cost of preventing business collapse are vital which the government should be doing. Hence, because of the above reason, serious action with welldetermined programs and donations are urgently required (Weiwen, Karen, \& Luedi, 2020). Therefore, to win the fight against the pandemic and to restore peace to the business community, everyone must make sure that the infection has decreased to the barest minimum through the adoption of regulatory measures from the health authorities. Individuals should be aware of the short-term effect caused by the pandemic in the system. Also, reliable micro and macro measures should be supported with effective controlling tools from the appropriate bodies concern (Agency, 2020).

As projected by many economists that there will be huge inevitable economic cost with a sharp increase in public debt that will be required to service the key part of income losses caused by the COVID-19 pandemic. Therefore, the major challenge is the sustenance of the widespread pandemic that could result in a lengthy global recession. Though the financial policy is creating a major contribution and a concrete, coordinated and strategy that involves monetary and financial sector policies, as well as commercial banks' involvement, becomes a stimulating package for SMEs to pick up again. Even though the financial sector suffered a crisis with serious capital needs, it was due to high levels of public and private debt (Frank, 2020). For a microeconomic unit such as the SMEs, a micro credits incentive is required through the microfinancial institutions with determining goals, but supervision and support should serve as the key to the financial institutions. Supporting businesses to maintain their employees is critical. Therefore, assistance in form of grants for the payment of salaries and wages, training and development, product innovation, and new production process can help to prevent organization downsizing. Internal assessment programs can assist businesses in understanding the internal environment and relate to production and business connections more effectively (Matt, 2020). 
Volume 3 Issue 7 (March 2021) PP. 75-92 DOI 10.35631/AIJBES.37007

\section{Challenges Facing Small Business during COVID-19 Pandemic}

According to a report from the International Monetary Fund (IMF) there is likely to experience a recession globally in the year 2020. Business sectors such as travel, accommodation, and food services will feel the pain more than other sectors. Generally, businesses are likely to undergo several stages of depression before regaining (Matt, 2020). The severity and damages caused by each of the stages hinge on the measures taken by various governments. The effect will be severe and the length of the pandemic will be unknown. For the fact that businesses travel from closure to regaining. Micro, small and medium scale enterprises will experience a combination of threats in the process of surviving the effect of the pandemic.

The demand for goods and services has risen and the majority of businesses have started showing a sign of liquidity problem due to the problem of cash reserves of SMEs. Hence any liquidity problem from this sector of the economy will result in liquidation in many other large businesses. International businesses are particularly vulnerable because of the shortage of US dollars for their transactions (Wuen and $\mathrm{Wu}, 2020$ ). For SMEs engaging in production activities, operations during lockdown become a problem because factory floors are not designed for social distancing. The movement of people to other places for the safety of life has resulted in the disappearance of workers and filling the gap created may be difficult for SMEs.

\section{Empirical Studies on the Effect of COVID-19 on SMEs Performance}

Several empirical studies were conducted by many researchers around the globe since the emergence of the pandemic called COVID-19, which has a devastating effect on the economy of many countries of the world. For instance, the study of Mogaji (2020) examined the impact of covid-19 on transportation in Lagos, Nigeria. Using a survey through a questionnaire administered to residents of Lagos via email in data collection and used descriptive analysis in his report. The findings revealed that lockdown and restrictions on movement have a significant positive effect on SME's performance. The findings indicate that economic activities, social activities, and religious activities during COVID-19 were affected by the disrupted transport services due to the pandemic. Additionally, the increased cost of transportation, shortage or lack of transportation mode, and traffic congestion were identified as the effect of COVID-19 on transportation in Lagos State, Nigeria, which also led to the increase in the overall cost of living in the city as well as an increase in the cost of food items.

In another study by Hamiza (2020) who conducted on the impact of Coronavirus Lockdown on Small and Medium Scale Businesses in Arua Municipality, Uganda, findings of the study revealed that lockdown has a significant positive effect on SMEs performance in Arua Municipal of Uganda. In their contribution, Ozili and Arun (2020) revealed that the increasing number of lockdown days, monetary policy decisions, and international travel restrictions have a significant positive effect on SME's performance. Furthermore, the findings indicate that restriction on internal movement and higher fiscal policy spending did not have a positive effect on SME's performance.

Also, Abideen (2020) who conducted on Coronavirus (COVID-19) and the Survival of Small and Medium Enterprises in Abeokuta, Ogun State Nigeria, the result of the study revealed that the COVID-19 sub-variables such as lockdown, movement restriction, and international travel restriction all have a significant negative relationship with the SMEs performance in Abeokuta, Ogun State Nigeria. 
Volume 3 Issue 7 (March 2021) PP. 75-92

DOI 10.35631/AIJBES.37007

However, from the reviewed works of few scholars above, it is obvious that the COVID-19 pandemic had led to some economic crises which have notable consequences on every individual and sectors of the economy as a whole. Still, there are yet to be explored empirical studies on the effect of coronavirus called COVID-19 on various economic activities and performance, more specifically on business owners and the performance of Small and Medium Scale Enterprises (SMEs) in some part of Nigeria. Therefore, based on this, it prompted the researchers to examine the COVID-19 pandemic and its effect on the performance of SMEs in Nigeria, specifically in Yobe State.

\section{Methodology}

This study was carried out in Yobe State, Nigeria. The study adopted a survey research design using a questionnaire which serves as an instrument to solicit the opinion of the respondents.

\section{Population and Sample}

The population for the study was 1000 registered SMEs in Yobe State. A sample of 278 SMEs was obtained by means of Krejcie and Morgan (1970) which was based on the formula $s=X^{2}$ $N P(1-P) \div d^{2}(N-1)+X^{2} P(1-P)$. Where $s=3.841 ; P=.50 ; d=.05 ; N=1000$ (population). Hence, $\mathrm{s}=3.841 \times 250 \div 2.4975+0.96025=960.25 \div 3.45775=277.71 s \approx 278$. Therefore, a simple random sampling techniques was used to select the participants across the state.

\section{Procedure for Data Collection}

The survey was carried out from September to December 2020. The questionnaire was administered to the respondents using 'drop and pick' method, i.e. keep and collect later and this was done with the help of three research assistance. This is to give the respondents enough time and comfort to critically respond to the items on the questionnaire. However, 278 questionnaires were administered to the respondents out of which 242 questionnaires were filled and retrieved by the researchers which are $87 \%$ of the total questionnaire administered and it is enough to provide a reliable result.

\section{Instrument Used for Data Collection}

The instrument used for the study was a questionnaire. It is divided into three sections. Section one on the demographic profile of the respondents. Section two on the independent variables. This section was divided into four parts A - D. Part A on the Lockdown measures with five items, for example, I find it difficult collecting debts owed me due to lockdown'. 'Production operations have been affected by the lockdown', this was adapted from Aderemi et al. (2020); part B on Movement Restriction five items, for example 'There is a great loss of customers due to movement restriction'. 'There is a reduction in customer traffic due to movement restriction' adapted from Hamiza (2020); part C on Market Closure with five items, for example, 'There is a loss of sales due to Market closure'. 'Market closure affects the demand for my products/services', adapted from Hamiza (2020); part D on Social Distancing with five items for example 'Social distancing policies affect business operations'. 'My business income has declined due to social distancing', adapted from Lutfi, Buntuang, and Hasanuddin (2020). Finally, Section Three was on the dependent variable - SME Performance five items, for example, 'The raw material and production costs have increased as a result of the pandemic'. 'My Supply chains are not as reliable as before because of the pandemic', adapted from Hamiza (2020) and Rathore and Khanna (2020). The instrument was prepared based on '5' points Likert Scale, 1 Strongly Disagree, 2 Disagree, 3 Undecided, 4 Agree and 5 Strongly Disagree. 
Data Analysis Techniques

DOI 10.35631/AIJBES.37007

Data collected for the study were analyzed using descriptive analysis, Pearson correlation, ANOVA, and regression using SPSS to answer the research questions.

\section{Results}

\section{Reliability Test}

The researcher conducted a reliability test to find out how reliable the measurements are as shown in Table 1 which contains the summary results of variables reliability, this shows the model's reliability. A reliability test is necessary to find out the reliability of the measurement model in respect of variables used in the study, which are Lockdown, Movement Restriction, Market Closure, and Social Distancing as independent variables and SMEs Performance as the dependent variable of the study.

Table 1 Reliability Test of the Variables of COVID-19

\begin{tabular}{lcc} 
Items & No of sub-items & Cronbach's Alpha \\
Lockdown & 5 & 0.795 \\
Movement Restriction & 5 & 0.840 \\
Market Closure & 5 & 0.765 \\
Social Distancing & 5 & 0.822 \\
SMEs Performance & 5 & 0.741 \\
\hline
\end{tabular}

Source: Authors Field Survey via SPSS

Table 1 above indicates all variables showed reliability values as their Cronbach's Alpha values higher than 0.70. It is therefore, concluded that all the constructs fall within very good reliability scores. As the rule of thumb states that Cronbach's Alpha coefficient represents 0.7 $<0.8$ is good and $0.8<0.9$ is very good.

\section{Respondents' Profile}

Table 2 Present the demographic profile of the respondents. It highlights to the users of the research finding the characteristics of the respondents in terms of gender, age, marital status, types of business, number of years in business, level of education, number of employees, and estimated yearly income as obtained in Table 2.

Table 2 Summary of the Demographic Factors of the Respondents

\begin{tabular}{lcc}
\hline Profile & Frequency $(\mathbf{n}=\mathbf{2 4 2})$ & Percentage \\
\hline Gender: & 214 & \\
Male & 28 & 88.4 \\
Female & & 11.6 \\
Age: & 57 & \\
Below 25 years old & 96 & 23.6 \\
Between 26 and 30 years & 89 & 39.7 \\
Above 30 years old & & 36.8 \\
Marital Status & 120 & \\
Single & 114 & 49.6 \\
Married & 08 & 47.1 \\
Others & & 3.3 \\
Types of Business: & 143 & \\
Sole Proprietorship & & 59.3
\end{tabular}


Partnership

Limited Liability

Co-operative

Number of Years in Business

0 -2 years

03-05 years

$6-10$ years

11 - above years

Level of Education:

Primary/Secondary school

NCE/ND

$\mathrm{BSc} / \mathrm{HND}$

Masters/PhD

Others

Number of Employees

$1-5$

$6-10$

$11-15$

$16-20$

21 - above

Estimated Yearly Income

$\$ 50,00$ - \$99,000 (\$132 - \$260)

$\$ 100,000$ - 149,000 (\$263 -

\$392)

$\$ 150,000$ - \$199,000 (\$395 -

$\$ 524)$

$\$ 200,000$ (\$526) and above
60

20

18

24.9

8.3

7.5

35

14.5

35.5

29.8

20.2

49

15.7

38

49.6

120

26.0

63

4.5

11

4.1

147

60.7

55

22.7

12.0

3.7

0.8

2

32.6

58

24.0

45

18.6

60

24.8

Source: Authors Field Survey via SPSS

\section{The Rated Level of Effect of COVID-19 on SMEs}

COVID-19 level of effect on SMEs was determined using descriptive analysis; the variables were analyzed and categorized into three (3) using Mean $(\overline{\mathrm{X}})$ of scores viz, (High, Moderate, and Low). The summary is provided in Tables 3, 4, 5, and 6 below:

Table 3 Extent to which SME Owners/Managers Rate the Effect of Lockdown on SMEs Performance

\begin{tabular}{ccccc}
\hline Rating & $\begin{array}{c}\text { Frequency } \\
(\mathbf{n = 2 4 2})\end{array}$ & Percentage & Mean & SD \\
\hline Low & 31 & 12.8 & 2.4711 & .71236 \\
Moderate & 66 & 27.3 & & \\
High & 145 & 59.9 & & \\
Total & 242 & 100.00 & & \\
\hline
\end{tabular}

Source: Authors Field Survey via SPSS

The descriptive analysis reveals that out of 242 total respondents, $145(59.9 \%)$ rated high level, $66(27.3 \%)$ rated within a moderate level, while $31(12.8 \%)$ were at a low level. This shows that the majority of the respondents $(87.2 \%)$ rated high and moderate levels on the effect of Lockdown on SMEs. In general, looking at the significant percentage $(87.2 \%)$ of those 
Volume 3 Issue 7 (March 2021) PP. 75-92 DOI 10.35631/AIJBES.37007

respondents that rated high and moderate levels in this study, it indicates that Lockdown has a serious effect on SME's performance.

Table 4 Extent to Which SME Owners/Managers Rate the Effect of Movement Restriction on SMEs Performance

\begin{tabular}{ccccc}
\hline Rating & $\begin{array}{c}\text { Frequency } \\
(\mathbf{n = 2 4 2})\end{array}$ & Percentage & Mean & SD \\
\hline Low & 26 & 10.7 & 2.5207 & .78292 \\
Moderate & 64 & 26.4 & & \\
High & 152 & 62.8 & & \\
Total & 242 & 100.00 & & \\
\hline
\end{tabular}

Source: Authors Field Survey via SPSS

Table 4 above indicates the descriptive analysis reveals that out of 242 total respondents, $152(62.8 \%)$ rated the variable at a high level, 64(26.4\%) rated within a moderate level, while $26(10.7 \%)$ were at a low level. This shows that the majority of the respondents $(89.2 \%)$ rated high and moderate levels on the effect of Movement Restriction on SMEs. In general, looking at the significant percentage $(89.2 \%)$ which rated high and moderate levels. Thus, respondents in this study indicate that Movement Restriction has a serious effect on SME's performance.

Table 5 Extent to Which SME Owners/Managers Rate the Effect of Market Closure on SMEs Performance

\begin{tabular}{ccccc}
\hline Rating & $\begin{array}{c}\text { Frequency } \\
(\mathbf{n = 2 4 2})\end{array}$ & Percentage & Mean & SD \\
\hline Low & 23 & 9.5 & 2.4669 & .76394 \\
Moderate & 83 & 34.3 & & \\
High & 136 & 56.2 & & \\
Total & 242 & 100.00 & & \\
\hline
\end{tabular}

Source: Authors Field Survey via SPSS

In Table 5 descriptive analysis reveals that out of 242 total respondents, $136(56.2 \%)$ rated market closure at a high level, 83(34.3\%) rated within a moderate level, while 23(9.5\%) were at a low level. This shows that the majority of the respondents $(90.5 \%)$ rated high and moderate levels on the effect of Market Closure on SMEs. In general, looking at the significant percentage $(90.5 \%)$ at the high and moderate levels. Thus, respondents in this study indicate that Market Closure has a serious effect on SME's performance.

Table 6 Extent to Which SME Owners/Managers Rate the Effect of Social Distancing on SMEs Performance

\begin{tabular}{ccccc}
\hline Rating & $\begin{array}{c}\text { Frequency } \\
(\mathbf{n = 2 4 2})\end{array}$ & Percentage & Mean & SD \\
\hline Low & 43 & 17.8 & 2.3017 & .7539 \\
& & & & 1 \\
Moderate & 83 & 34.3 & & \\
High & 116 & 47.9 & & \\
Total & 242 & 100.00 & \\
\hline
\end{tabular}

Source: Authors Field Survey via SPSS 
Volume 3 Issue 7 (March 2021) PP. 75-92

DOI 10.35631/AIJBES.37007

Finally, in Table 6 above, the descriptive analysis reveals that out of 242 total respondents, $116(47.9 \%)$ rated social distancing at a high level, 83(34.3\%) rated within a moderate level, while $43(17.8 \%)$ were at a low level. This shows that majority of the respondents $(82.2 \%)$ rated at the high and moderate levels on the effect of Social Distancing on SMEs. In general, looking at the significant percentage $(82.2 \%)$ at the high and moderate levels. Thus, respondents in this study indicate that Social Distancing affects SME's performance.

\section{Correlation Analysis}

Table 7 shows the relationship between the predictor and the dependent variables. The variables displayed consist of SME's performance as the (DV) while the predictor variables were Lockdown, Movement Restriction, Market Closure, and Social Distancing as the (IVs).

Table 7 Pearson Correlation between Variables Lockdown, Movement Restriction, Market Closure, Social Distancing, and SMEs Performance

\begin{tabular}{llllll} 
Lockdown (X1) & 1 & $.560^{* *}$ & $.419^{* *}$ & $.298^{* *}$ & $.444^{* *}$ \\
Movement Restriction (X2) & 1 & $.587^{* *}$ & $.403^{* *}$ & $.565^{* *}$ \\
Market Closure (X3) & & 1 & $.497^{* *}$ & $.570^{* *}$ \\
Social Distancing (X4) & & & 1 & $.391^{* *}$ \\
SMEs Performance (Y) & & & & 1 \\
\hline
\end{tabular}

**. Correlation is significant at the 0.01 level (2-tailed). Source: Authors Field Survey via SPSS

Table 7 above, indicates COVID-19 variable that has the highest correlation of 0.570 is Market Closure, which means it has the highest positive effect on SME's performance. Variables such as Movement Restriction and Lockdown also recorded positive correlation values of 0.565 and 0.444 respectively with SME's performance. Lastly, Social Distancing recorded a low positive correlation value of 0.391 with SME's performance. This means business activities are seriously affected by COVID-19. This portrays the present situation of SMEs in Yobe State due to the COVID-19 pandemic. It also shows how SMEs are battling with lockdown, movement restriction, market closure, and social distancing which could lead to a business shutdown.

The multiple linear regression model used for this research is indicated in mathematical terms as follows:

$\mathrm{Y}=\beta 0+\beta 1 \mathrm{LD} 1+\beta 2 \mathrm{MR} 1+\beta 3 \mathrm{MC} 1+\beta 4 \mathrm{SD} 1+\mu \mathrm{i} \ldots \ldots \ldots \ldots . \mathrm{Eq}(1)$

Where $\mathrm{Y}=$ SME Performance is the state of Small and Medium Enterprises (DV), LD = Lockdown (IV), MR = Movement Restriction (IV), MC = Market Closure (IV), and SD = Social Distancing (IV)

Multiple Regression Analysis

The study came up with a model which is shown in Table 8 as a summary.

Table 8 Model Summary showing Variables of COVID19 Effect on SME Performance

\begin{tabular}{lcccc}
\hline & & & Adjusted R & Std. Error of \\
Model & $\mathrm{R}$ & R Square & $\begin{array}{c}\text { Square } \\
\text { the Estimate }\end{array}$ \\
1 & $.652^{\mathrm{a}}$ & .425 & .415 & .48855 \\
\hline
\end{tabular}


a. Predictors: (Constant), Social Distancing, Lockdown,

Movement Restriction Market Closure,

Source: Authors Field Survey via SPSS

b. Dependent Variable: SMEs Performance

Table 8 above indicates the variables score an Adj. $\mathrm{R}^{2}$ of $41.5 \%$ as shown in Table 8 . However, the $41.5 \%$ Adj. $\mathrm{R}^{2}$ is an indication that there are other unexplained variables $58.5 \%$, which are not considered in this study.

The model was tested in the study by ANOVA, and the results indicated in Table 9 below:

Table 9 ANOVA showing the Effect of COVID-19 Variables on SME Performance

\begin{tabular}{|c|c|c|c|c|c|c|}
\hline \multicolumn{2}{|c|}{ Model } & $\begin{array}{l}\text { Sum of } \\
\text { Squares }\end{array}$ & df & $\begin{array}{l}\text { Mean } \\
\text { Square }\end{array}$ & $\mathrm{F}$ & Sig. \\
\hline 1 & $\begin{array}{l}\text { Regressio } \\
\mathrm{n}\end{array}$ & 41.729 & 4 & 10.432 & 43.708 & $.000^{\mathrm{b}}$ \\
\hline & Residual & 56.568 & $\begin{array}{r}23 \\
7\end{array}$ & .239 & & \\
\hline & Total & 98.298 & $\begin{array}{r}24 \\
1 \\
\end{array}$ & & & \\
\hline
\end{tabular}

a. Dependent variable: SMEs performance.

b. Predictor: (Constant), Social Distancing, Lockdown, Market

Closure, Movement Restriction

Source: Authors Field Survey via SPSS

The goodness fit for the model was tested using ANOVA and the F value of the predictor was observed to be 43.708 and was significant at 0.000 making the model fit.

The regression analysis of the study was conducted that determined the most significant variables (market closure, movement restriction, lockdown, and social distancing) which influence the SME's performance. The data presented in Table10

Table 10 Correlation Coefficients showing the Effect of Variables of COVID-19 on SME Performance

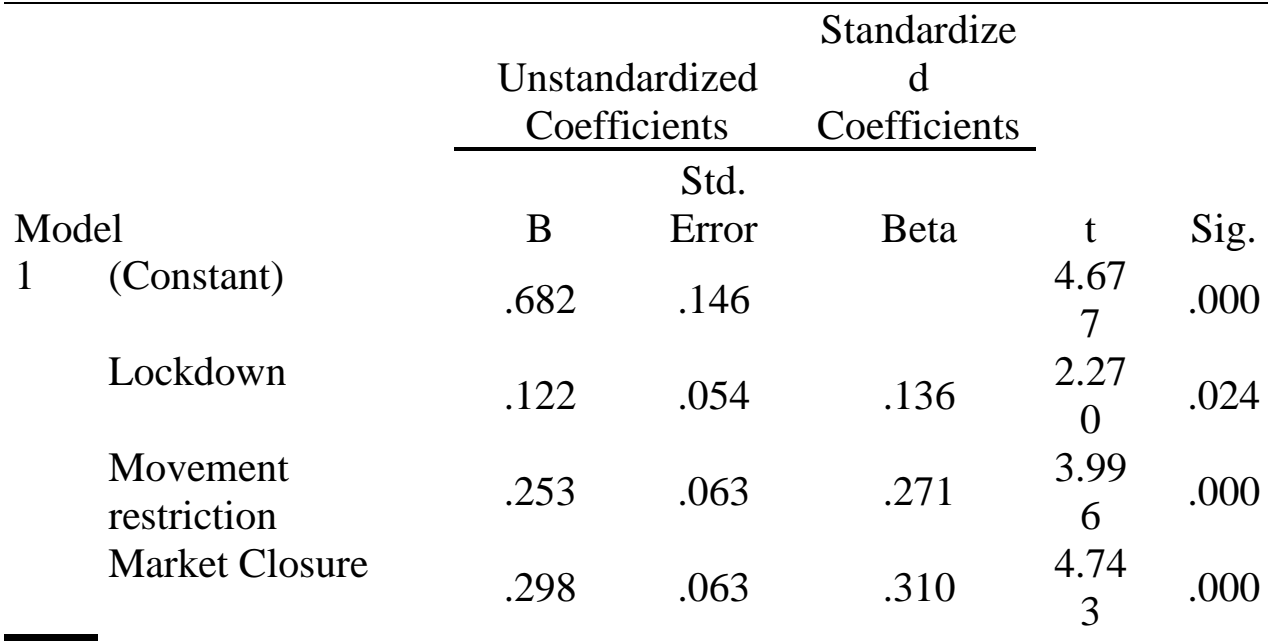


Volume 3 Issue 7 (March 2021) PP. 75-92 DOI 10.35631/AIJBES.37007

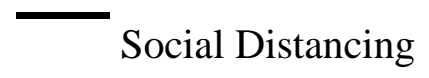
.074 .049 1.51 .131

a. Dependent Variable: SMEs Performance

Source: Authors Field Survey via SPSS

Table 10 provide answers to the RQ 2 which were stated based on RO 2. The results indicate that there is a positive significant effect of three independent variables (market closure, movement restriction, and lockdown) on the dependent variable which is SMEs performance. While one variable social distancing indicates an insignificant effect on the dependent variable SME performance. Furthermore, the result indicated that market closure has the highest beta value of 0.310 , the second-highest value is movement restriction with a beta value of 0.271 , followed by lockdown with a beta value of 0.136 these higher values indicated a positive significant effect on the SME's performance. This indicates that these variables of the COVID19 pandemic mentioned above have the most significant effect on the small and medium enterprises (SMEs). The SMEs are now turning to battle with market closure, movement restriction and lockdown are even considering the possibilities of restructuring due to consumers not patronizing their products resulting in a decrease in demand. They are having a second thought of reshuffle businesses and have the fear they might exit the business. These factors hanging on the necks of SMEs are a result of the COVID-19 global pandemic that has affected every activity of SMEs.

\section{Discussion}

The findings revealed that the COVID-19 pandemic has seriously affected the performance and existence of SMEs in Nigeria. Considering variables lockdown, movement restrictions, market closure, and social distancing to measure the effect of this pandemic on SME's in Yobe State Nigeria. These variables were selected to show the nature of the devastating effect of this pandemic on businesses in Yobe State Nigeria. All the variables had a positive and significant effect on SME's performance except social distancing. Thus, the findings of this study are consistent with the studies conducted by Jasmine, (2019) and Korankye, (2020).

\section{Conclusion}

In conclusion, the study's findings indicate that the COVID-19 pandemic has a devastating effect on SMEs performance in Yobe State Nigeria, which may eventually lead to the shutdown of some businesses due to a reduction in demand and supply, reduction in revenue, and several workers in some instances laying off. Consumers are not patronizing their products resulting in the high cost of doing business without returns. Some SMEs are reorganizing themselves to remain efficient and survive amidst COVID-19. Some businesses also are in a state of fear of losing all investments or being kicked out of business. This is the situation SMEs find themselves in light of this global pandemic in Nigeria.

\section{Recommendation}

COVID-19 pandemic causing more disaster than good to businesses, individuals, and governments. Therefore, a decisive measure should put in place to keep and maintain businesses. Though, the Federal Government of Nigeria is providing stimulus called COVID19 relief packages to give support to SMEs. The following recommendations were given:

1. Proactive plans should put in place in anticipation of events such as COVID-19 that most likely affect the organizations.

2. Businesses should adopt online or digital sales and services. 
Volume 3 Issue 7 (March 2021) PP. 75-92

DOI 10.35631/AIJBES.37007

3. Astringent macroeconomic monetary and fiscal policies are institutionalized and formulated to help SMEs during the period of hardship such as COVID-19 pandemic

4. Businesses should improve on their mode of communication, they should communicate early with employees on policies and procedures, changes, engaging with worker's unions where appropriate.

5. Businesses should desist from doing business that is risky in this period.

6. The government and business enterprises in all sectors should join hands together and help each other for the quick recovery of the SMEs and the economy in general.

\section{Limitations}

The study is also like all other studies have some limitations. Therefore, first and foremost the study has a limitation in terms of the area of the study. The study is limited to Yobe State and therefore cannot represent other SMEs elsewhere. Secondly, the variables are limited to four which explain $41.5 \%$ effect on SME performance meaning that there are $58.5 \%$ unexplained effect by other variables which are not considered in this study and may be related to COVID19. Therefore, future researchers should consider other variables which are different from the variables used in this study. Through further research may be new findings will have emerged.

\section{References}

Abideen, S. O. (2020). Coronavirus (COVID-19) and the Survival of Small and Medium Enterprises in Abeokuta, Ogun State Nigeria Scholars Journal of Economics, Business and Management, 07(06), 209-214.

Abosede, A. J., \& Onakoya, A. B. (2013). Entrepreneurship, economic development, and inclusive growth. International Journal of Social Sciences and Entrepreneurship, 1(3), 375-387.

Aderemi, T. A., Ojo, L. B., Ifeanyi, O. J., \& Efunbajo, S. A. (2020). Impact of Corona Virus (COVID-19) Pandemic on Small and Medium Scale Enterprises (SMEs) in Nigeria: A Critical Case Study. Acta Universitatis Danubius. Economica, 16(4).

Aderemi, T. A., Olu-Young, F., Taiwo, A. A., \& Adejumo, O. O. (2019). Agripreneurship Financing and Agricultural Development Nexus in Nigeria: Prospects or Problems? International Journal of Accounting Research, 4(4), 1-7.

Agency, X. N. (2020). Analysis of Regional Policies on Businesses Reopening Support, China Economic Information Service, Economic Analysis Report No. 1048, Epidemic Series No. 2, February 17.

Akanni, L., \& Gabriel, S. (2020). The Implication of Covid19 on the Nigerian Economy. Centre for the Study of the Economies of Africa (CSEA). Accessed on April 15th.

Alaye-Ogan, E. (2012). A practical guide to running successful small businesses in Nigeria: challenges, peculiarities, and effective resolution support. Deutschland: Lambert Academic Publishing.

Andam, K., Edeh, H., Oboh, V., Pauw, K., \& Thurlow, J. (2020). Impacts of COVID-19 on food systems and poverty in Nigeria. Advances in Food Security and Sustainability, 5, 145.

Bookchin, M. (1960). Post-scarcity anarchy: Chadwyck-Healey Incorporated.

Boulding, K. E. (1956). Some contributions of economics to the general theory of value. Philosophy of Science, 23(1), 1-14.

CBN. (2018). SMEs financing in Nigeria. Accessed on the 27th of January, 2019 http://www.cenbank.org. 
Volume 3 Issue 7 (March 2021) PP. 75-92

DOI 10.35631/AIJBES.37007

Central Bank of Nigeria. (2020). "Contributions/Donations to CBN-Led COVID-19 Relief Fund Account Domiciled with the Central Bank of Nigeria”, Central Bank of Nigeria, 8 April, available at https://www.cbn.gov.ng/Out/2020/CCD/covid\%20contributions.pdf (accessed 4 July 2020).

Craven, M., Liu, L., Mysore, M., \& Wilson, M. (2020). COVID-19: Implications for business. McKinsey \& Company.

Durkheim, E. (1984). The division of labor in society: Macmillan: Basingstoke.

Edgecliffe-Johnson, A. (2020). Coronavirus lay-offs split corporate America. Financial Times, New York. Accessed from www.ft.com.

Erdem, F., Erdem, S. (2011). Functional strategies and practices of small and medium-sized family businesses. International Journal of Islamic and Middle Eastern Finance and Management, 4(2), 174-185.

Fabeil, N. F., Pazim, K. H., \& Langgat, J. (2020). The Impact of Covid-19 Pandemic Crisis on Micro-Enterprises: Entrepreneurs' Perspective on Business Continuity and Recovery Strategy. Journal of Economics and Business, 3(2), 837-844.

Farrell, D., \& Wheat, C. (2016). Cash is King: Flows, Balances, and Buffer Days Evidence from 600,000 Small Businesses. JPMorgan Chase \& Co Institute.

Fernandes, N. (2020). Economic effects of coronavirus outbreak (COVID-19) on the world economy. Available at SSRN 3557504., 1-26.

Frank T. (2020). Coronavirus: China Grants Banks Extra Funding to Spur Loans to Hard-Hit Small Businesses, South China Morning Post, February 26, 2020. Online @ https://www.scmp.com/economy/article/3052474/coronovirus-china-grants-banksextra-funding-spur-loans-hard.

Friedman, B. D., \& Allen, K. N. (2011). Systems theory. Theory \& Practice in Clinical Social Work, 2(3), 3-20.

Garba, A. (2020). Effect of COVID 19 on Small and Medium Scale Enterprises Performance in Makurdi Metropolis, Benue State, Nigeria. GRA's Multidisciplinary International (GRAM i) Journal, 4(6), 1-11.

Gbandi, E., \& Amissah, G. (2014). Financing options for small and medium enterprises (SMEs) in Nigeria. European Scientific Journal, 10(1), 2047-2061.

Hamiza, O. (2020). The Impact of Coronavirus Lockdown on Small Scale Businesses in Arua Municipality, Uganda. International Journal of Science and Research (IJSR), 9(8), 1239-1248.

Harapan, H., Itoh, N., Yufika, A., Winardi, W., Keam, S., Te, H., Mudatsir, M. (2020). Coronavirus disease 2019 (COVID-19): A literature review. Journal of Infection and Public Health, 13(2020), 667-673.

Hatzius, J., Philips, A., Mericle, D., \& Struyven, D. (2020). US Daily: a sudden stop for the US economy. Economic Research in Goldman Sachs.

Igwe, P. A. (2020). Coronavirus with Looming Global Health and Economic Doom. African Development Institute of Research Methodology.

ILO. (2017). "World employment social outlook. Sustainable enterprises and jobs: formal enterprises and decent work", International Labor Organization, Geneva, 145.

IMF. (2020 ). Policy-Responses-to-COVID-19. International Monetary Fund. Retrieved from www.imf.org.

Jasmine, C. A. (2019). Impacts of Covid-19 on Company and Efforts to Support Organization Adaptable. Dr. David F. Rico, PMP, ACP, CSM, 67-70. 
Volume 3 Issue 7 (March 2021) PP. 75-92 DOI 10.35631/AIJBES.37007

Korankye, B. (2020). The Impact of Global Covid-19 Pandemic on Small and Medium Enterprises in Ghana. International Journal of Management, Accounting, and Economics, 7(6), 320-341.

Krejcie, R. V., \& Morgan, D. W. (1970). Determining sample size for research activities. Educational and Psychological Measurement, 30(3), 607-610.

Lutfi, M., Buntuang, P. C. D., \& Hasanuddin, B. (2020). The impact of social distancing policy on small and medium-sized enterprises (SMEs) in Indonesia. Problems and Perspectives in Management, 18(3), 492.

Matt, C., Linda L., and Matt W. . (2020). COVID-19: Implications for Business, McKinsey \& Company, March 2020. Online@ @https://www.mckinsey.com/businessfunctions/risk/our-insight/covid-19-implications-for business.

Mogaji, E. (2020). Financial vulnerability during a pandemic: insights for coronavirus disease (COVID-19). Mogaji, E, 57-63.

Moore, N. (2020). Chloroquine for COVID-19 infection: Springer.

National Bureau of Statistics. (2020). Annual Statistics Report, Abuja, Nigeria

Ohia, C., Bakarey, A. S., \& Ahmad, T. (2020). COVID-19 and Nigeria: putting the realities in context. International Journal of Infectious Diseases, 95(2020), 279-281.

Ozili, P. K. (2020). Covid-19 pandemic and economic crisis: The Nigerian experience and structural causes. Accessed at SSRN 3567419.

Ozili, P. K., \& Arun, T. (2020). Spillover of COVID-19: Impact on the Global Economy. Accessed at SSRN 3562570.

Rathore, U., \& Khanna, S. (2020). From Slowdown to Lockdown: Effects of the COVID-19 Crisis on Small Firms in India. Available at SSRN 3615339.

Rebmann, T., Wang, J., Swick, Z., Reddick, D., \& del Rosario Jr, J. L. (2013). Business continuity and pandemic preparedness: US health care versus non-healthcare agencies. American Journal of Infection Control, 41(4), e27-e33.

Schrank, H. L., Marshall, M. I., Hall-Phillips, A., Wiatt, R. F., \& Jones, N. E. (2013). Smallbusiness demise and recovery after Katrina: rate of survival and demise. Natural Hazards, 65(3), 2353-2374.

Shereen, M. A., Khan, S., Kazmi, A., Bashir, N., \& Siddique, R. (2020). COVID-19 infection: Origin, transmission, and characteristics of human coronaviruses. Journal of Advanced Research, 24(2020), 91-98.

Sullivan-Taylor, B., \& Branicki, L. (2011). Creating resilient SMEs: why one size might not fit all. International Journal of Production Research, 49(18), 5565-5579.

Tehseen, S., \& Ramayah, T. (2015). Entrepreneurial competencies and SMEs business success: The contingent role of external integration. Mediterranean Journal of Social Sciences, $6(1), 50-50$.

Turner, J., \& Akinremi, T. (2020). The business effects of pandemics-a rapid literature review. Enterprise Research Centre, available at https://www. enterpriseresearch. ac. uk/wpcontent/uploads/2020/04/ERC-Insight-The-business-effects-of-pandemics-\% E2, 80.

UNDP, N. (2020). The impact of the Covid-19 pandemic in Nigeria. A socio-economic analysis, 4-12. Retrieved from www.undp.org.

Unhale, S. S., Ansar, Q. B., Sanap, S., Thakhre, S., Wadatkar, S., Bairagi, R., . . . Biyani, K. (2020). A review on coronavirus (COVID-19). World Journal of Pharmaceutical and Life Sciences, 6(4), 109-115.

von Bertalanffy, L. (1951). Towards a physical theory of organic teleology. Human Biology, 23(4), 346.

Weiwen Han Karen Harris Thomas Luedi. (2020). "How much will coronavirus hurt China's economy?", Bain \& Company, Snap Chart,

Copyright $\odot$ GLOBAL ACADEMIC EXCELLENCE (M) SDN BHD - All rights reserved 
Volume 3 Issue 7 (March 2021) PP. 75-92

DOI 10.35631/AIJBES.37007

WHO. ( 2020). Timeline of WHO's response to COVID-19. World Health Organization. Retrieved from www.who.int

Wuen H. L. and Wu J. F. (2020). 'Research Report on Companies' Survival and Development Strategy During a Noval Coronavirus Epidemic, Beijing: UIBE Press, February 2020. 